\title{
Growth Arrest-Specific 6 (Gas6) and TAM Receptors in Mouse Platelets
}

\section{Fare Trombositlerinde "Growth Arrest-Specific 6" (Gas6) ve TAM Reseptörleri}

\author{
Fikriye Uras' ${ }^{1}$ Burhanettin Küçük1, Özlem Bingöl Özakpınar ${ }^{1}$, Ahmet Muzaffer Demir² \\ ${ }^{1}$ Marmara University Faculty of Pharmacy, Department of Biochemistry, İstanbul, Turkey \\ ${ }^{2}$ Trakya University Faculty of Medicine, Department of Hematology, Edirne, Turkey
}

\begin{abstract}
:
Objective: Growth arrest-specific 6 (Gas6) is a newly discovered vitamin K-dependent protein, which is a ligand for TAM receptors [Tyro3 (Sky), Axl, and Mer] from the tyrosine kinase family. Gas6 knockout mice were resistant to venous and arterial thrombosis. There are contradictory reports on the presence of Gas6 and its receptors in mouse platelets. The objective of this study was to investigate whether Gas6 and its receptors were present in mouse platelets or not.

Materials and Methods: Specific pathogen-free BALB/c male and female mice of 8-10 weeks old and 25-30 g in weight were anesthetized under light ether anesthesia and blood samples were taken from their hearts. RNAs were isolated from isolated platelets, and then mRNAs encoding Gas6 and TAM receptors were detected by reverse transcription-polymerase chain reaction (RT-PCR). Protein concentrations of Gas6 and TAM receptors in platelets were measured by ELISA, but not those of Mer, because of the absence of any commercial ELISA kit for mouse specimens.

Results: RT-PCR results indicated the presence of mRNAs encoding Gas6 and Mer in mouse platelets. However, although RTPCR reactions were performed at various temperatures and cycles, we could not detect the presence of mRNAs encoding Axl and Tyro3 (Sky). Receptor protein levels of Axl and Tyro3 were below the detection limits of the ELISA method.

Conclusion: We found the presence of mRNAs encoding Gas6 and the receptor Mer in mouse platelets, but not Axl and Tyro3. Gas6, Axl, and Tyro3 protein levels were below the detection limits of the ELISA. The presence of mRNA is not obvious evidence of protein expression in platelets that have no nucleus or DNA. Further studies are required to clarify the presence of Gas6/TAM receptors in platelets using real-time PCR and more sensitive immunological methods, and future studies on mechanisms will indicate whether the Gas6/TAM pathway is a strategy for treatment of disorders.
\end{abstract}

Key Words: Blood platelets, Growth arrest-specific protein 6, Hemostasis

Özet:

Amaç: Gas6 proteini (growth arrest specific 6), K vitaminine bağımlı protein ailesinin yeni bir üyesi olup reseptör tirozin kinazlardan TAM reseptörlerinin [Tyro3 (Sky), Axl ve Mer] bir ligandıdır. Gas6 geni susturulmuş farelerin, venöz tromboembolizme daha dirençli oldukları görülmüştür. Fare trombositlerinde Gas6 proteininin var olup olmadığı konusunda birbiriyle çelişkili yayınlar bulunmaktadır. Biz bu araştırmada, fare trombositlerinde Gas6 proteini ve reseptörlerinin varlığını hem mRNA hem de protein seviyesinde araştırmayı amaçladık.

Address for Correspondence: Fikriye URAS, M.D.,

Marmara University Faculty of Pharmacy, Department of Biochemistry, İstanbul, Turkey

E-mail: furas@marmara.edu.tr

Received/Geliş tarihi : March 17, 2013

Accepted/Kabul tarihi : June 24, 2013 
Gereç ve Yöntemler: Spesifik patojen içermeyen 8-10 haftalık, 25-30 gr ă̆ırlı̆ıındaki Balb-C ırkı dişi/erkek fareler hafif eter anestezisi altında bayıltıp, kalpten kan örnekleri alındı. Önce trombositlerden mRNA'lar elde edildi. Daha sonra ters transkripsiyon-polimeraz zincir reaksiyonu (RT-PCR) yöntemiyle Gas6 ve TAM reseptörlerinin herbirini kodlayan mRNA'lar araştırıldı. Trombositlerdeki Gas6 ve TAM reseptör proteinleri ELISA yöntemiyle ölçüldü. Ancak farede Mer protein seviyesini ölçen bir ELISA kiti henüz üretilmediği için Mer seviyesi ölçülemedi.

Bulgular: RT-PCR sonuçları fare trombositlerinde Gas6 ve Mer'i kodlayan mRNA'ların var olduğunu gösterdi. Çeşitli sıcaklık ve döngülerde RT-PCR deneyleri yapıldığı halde, Axl ve Tyro3'e (Sky) ait mRNA varlı̆̆ı saptanamadı. Gas6, Axl ve Tyro3 (Sky) protein seviyeleri ELISA yöntemlerinin en düşük ölçüm sınırlarının altındaydı.

Sonuç: Biz fare trombositlerinde, Gas6 ve onun reseptörlerinden sadece Mer'i kodlayan mRNA'ların var olduğunu bulduk ama Axl ve Tyro3'ü kodlayan mRNA'ların varlığını saptayamadık. Protein olarak Gas6, Axl ve Tyro3 seviyeri, ELISA yöntemlerinin ölçüm limitlerinin altındaydı. Trombositlerde mRNA'ların var olması, protein sentezinin burada yapıldığının kesin bir kanıtı değildir. Çünkü trombositlerde DNA yoktur. Trombositlerde Gas6/TAM reseptörlerinin varlığını daha iyi aydınlatmak için Gerçek Zamanlı-PCR ve yüksek duyarlılığa sahip immunolojik yöntemlerle yapılacak ileri araştırmalara ihtiyaç vardır. Bu moleküllerin fizyolojik mekanizması aydınlatıldığında hastalıkların tedavisinde yeni bir strateji olabilir.

Anahtar Sözcükler: Trombositler, Growth arrest-specific protein 6, Hemostaz

\section{Introduction}

The number of newly discovered vitamin K-dependent proteins has been increasing. These include osteocalcin, matrix Gla protein, Gla-rich protein, periostin, and growth arrestspecific gene 6 (Gas6). The Gas6 protein was first described as a vitamin K-dependent protein by Manfioletti et al. in 1993 [1]. Human Gas6 was mapped to chromosome 13q34 [2]. Gas6, a $75-\mathrm{kDa}$ protein, has $44 \%$ sequence homology to natural anticoagulant protein $S$, but has no anticoagulant activity [1,3]. Both Gas6 and protein S have affinity to TAM receptors [Tyro3 (Sky), Axl, and Mer] from the receptor tyrosine kinase family [4]. Unlike the other vitamin K-dependent proteins, the primary site of synthesis for Gas6 is not the liver. However, it is expressed in endothelial cells [1], vascular smooth muscle cells [5], bone marrow cells [6], and normal and malignant hematopoietic cells [7].

Gas6 has structural domains: a carboxy-terminal domain that is similar to the sex hormone-binding globulin, 4 epidermal growth factor-like domains, and a $\gamma$-carboxylated amino-terminal domain (Gla domain) consisting of 11 glutamic acid residues [8,9]. The Gla domain, which forms complexes with calcium ions, is unique to vitamin K-dependent proteins. In the endoplasmic reticulum, some glutamate residues are posttranslationally modified by a vitamin K-dependent reaction [10]. Without the Gla domain the clotting factors cannot bind to phospholipid receptors on the surface of platelets. This binding is essential for the activation of the coagulation pathway $[11,12,13]$. In the absence of carboxylation, the coagulation process becomes defective $[14,15]$. In a conformationally specific manner, Gla residues can coordinate themselves to bind to cell membranes [16]. This interaction was shown to mediate both Gas6 and protein S binding to apoptotic cells [10].
It has been shown that Gas6 has a role in some physiological processes including cell growth arrest, bone resorption, phagocytosis of apoptotic cells, cell survival, cell proliferation, cell migration, and cell adhesion $[1,17,18,19,20,21,22]$. Gas6 binds to TAM receptors with markedly different affinities $[23,24]$. Axl was first isolated from chronic myelogenous leukemia patients in 1991 [25]. It was detected in some organs and cell lines including hematopoietic, mesenchymal, and epithelial cells [26].

In 1994, Tyro3 (Sky) was reported as a novel receptor [27]. The genomic structure is very similar to human Tyro3 and it is expressed in embryonic cells [28]. Mer was first identified in 1994 and its mRNA is present in bone marrow and monocytes $[29,30]$.

Gas6 knockout mice experiments showed that these mice were resistant to venous and arterial thrombosis [31]. It was also shown that TAM receptor knockout mice were resistant to thrombosis and degradation of platelet aggregation [32]. It was suggested that Gas6 increases the tendency to thrombosis by leading to platelet plaque stabilization. The role of Gas6 and its receptors on platelets is uncertain.

There is disagreement as to whether synthesis of Gas6 in mouse platelets plays a role in these alterations. Some research groups have reported contradictory results for the presence of Gas6 and its receptors in mouse platelets. The presence of Gas6 and its 3 receptors was shown in both human and mouse platelets [31]. Chen et al. found the presence of Gas6 in mice platelets and only Mer from the TAM receptors [33]. Gould et al. showed the presence of each of the 3 receptors of TAM in mouse platelets [34]. It is obvious that there are contradictory findings related to the presence of Gas6 and its receptors in platelets. The objective of the present study was to clarify disagreement on the existence of Gas6 and TAM receptors in platelets. 


\section{Materials and Methods}

Mice

Specific pathogen-free BALB/c male and female mice of 8-10 weeks old and 25-30 g in weight were obtained from the Experimental Research and Animal Laboratory of Marmara University (İstanbul, Turkey). All of the experimental procedures were conducted according to the guidelines of the Animal Care and Use Committee of Marmara University.

\section{Isolation of Mice Platelets}

Mice were anesthetized under light ether anesthesia and blood samples were collected from their hearts into tubes containing a 1:9 ratio of sodium citrate (3.2\%). Platelet-rich plasma was isolated after centrifugation of whole blood at $200 \mathrm{x} g$ for $10 \mathrm{~min}$. The supernatant was transferred into an Eppendorf tube for centrifugation at $1000 \mathrm{x}$ g for $10 \mathrm{~min}$. Platelet pellets were suspended in a HEPES-Tyrode buffer $(\mathrm{pH}$ 7.4) containing $1 \mu \mathrm{g} / \mathrm{mL}$ prostacyclin and then centrifuged at $1000 \mathrm{x}$ g for $10 \mathrm{~min}$.

\section{Reverse Transcription-Polymerase Chain Reaction (RT-PCR)}

Total RNA was isolated from platelets using a NucleoSpin RNA XS kit in line with the manufacturer's instructions (Macherey-Nagel, Düren, Germany). The primers, obtained from Invitrogen, were as follows: those that generated a 400bp Gas6 PCR product, 5'-CGG CAT TCC CTT CAA GGA GAG T-3' (Gas6 forward; 1459-1480) and 5'-CTC AAC TGC CAG GAC CAC CAA CT-3' (Gas6 backward; 1836-1868); those that generated a 238-bp Mer PCR product [35], 5'GCA GGG ACT TAC AAA GAG CTT TCT-3' (Mer forward; 1309-1332) and 5'-AGC CGA GGA TGA TGA ACA TAG AGT-3' (Mer backward; 1542-1566); those that generated a 400-bp Axl PCR product [36], 5'-AGG CTC ATT GGC GTC TGT T-3' (Axl forward; 2004-2033) and 5'-ATC GCT CTT GCT GGT GTA G-3' (Axl backward; 2385-2403); and those that generated a 445-bp Tyro3 PCR product [37], 5'GGA AGA GAC GCA AGG AGA C-3' (Tyro3 forward; 16001620) and 5'-ATG GGA ATG GGG AGA CGA C-3' (Tyro3 backward; 2027-2045). For each sample, $3 \mu \mathrm{L}$ of total RNA was used. RT-PCR was performed with the QIAGEN OneStep PCR kit (QIAGEN, Düsseldorf, Germany) according to the manufacturer's instructions. The same application for all genes was performed with reverse transcription at $50^{\circ} \mathrm{C}$ for 30 min, PCR activation at $95^{\circ} \mathrm{C}$ for $15 \mathrm{~min}$, and final extension at $72{ }^{\circ} \mathrm{C}$ for $10 \mathrm{~min}$. The following parameters for amplification were selected: Gas6, 38 cycles, denaturation at $94^{\circ} \mathrm{C}$ for $30 \mathrm{~s}$, annealing at $58{ }^{\circ} \mathrm{C}$ for $30 \mathrm{~s}$, extension at $72{ }^{\circ} \mathrm{C}$ for $1 \mathrm{~min}$; Mer, 35 cycles, same as the procedure for Gas 6 except for annealing at $55^{\circ} \mathrm{C}$ for $30 \mathrm{~s}$; Tyro3, 38 cycles, same as the procedure for Gas6 except for annealing at $52{ }^{\circ} \mathrm{C}$ for $30 \mathrm{~s}$; Axl, 35 cycles, same as the procedure for Gas6 except for annealing at $55^{\circ} \mathrm{C}$ for $30 \mathrm{~s}$. Using 2\% agarose gel, PCR products were subjected to electrophoresis $(100 \mathrm{~V})$ and visualized with ethidium bromide (1\%). These experiments were repeated 3 times with different sets of animals.

\section{Enzyme-Linked Immunosorbent Assay (ELISA)}

Concentrations of Gas6, Axl, and Tyro3 in mouse plasma and platelets were measured with DuoSet ELISA kits (R\&D Systems, Minneapolis, MN, USA) according to the manufacturer's recommendations. Due to the lack of a commercial ELISA kit for Mer, we were unable to assay it. In brief, a 96-well microtiter plate was coated and incubated overnight at $4{ }^{\circ} \mathrm{C}$ with $100 \mu \mathrm{L}$ of capture antibody. Phosphate-buffered saline Tween-20 (PBST) was used as the washing buffer, comprising phosphate-buffered saline (PBS) containing $0.1 \%$ Tween-20. All washing steps were carried out 5 times between steps. Wells were blocked with $1 \%$ bovine serum albumin (BSA) in PBST for $1.5 \mathrm{~h}$ at room temperature. Platelets were lysed by freezing/thawing [13] and $100 \mu \mathrm{L}$ of calibrators or samples was added to the wells in 10-, 20-, or 40 -fold dilutions. Wells were incubated for $1 \mathrm{~h}$ at $37^{\circ} \mathrm{C}$ and the manufacturer's instructions were then followed. The reaction was stopped after $20 \mathrm{~min}$ of incubation by addition of $100 \mu \mathrm{L}$ of $2 \mathrm{~N} \mathrm{H}_{2} \mathrm{SO}_{4}$. Optical density was measured at 450 $\mathrm{nm}$ on an ELISA reader.

\section{Statistical Analysis}

Descriptive statistics were reported as median (25th percentile-75th percentile) for mouse plasma Gas6 concentrations.

\section{Results}

Platelets isolated in blood and flow cytometric analysis demonstrated the high purity ( $>93 \%)$ of the platelet preparation when we used CD41 as a marker. After isolation of total RNA from the platelets, the RT-PCR studies were carried out with suitable primers belonging to Gas6 and TAM receptors. Gas6 (400 bp) and Mer receptor (238 bp) gene amplification products were detected in mouse platelets, indicating the presence of mRNAs of Gas6 and Mer (Figure 1). However, for Axl and Tyro3, no appreciable PCR products were detected, which indicated no significant mRNA of Axl or Tyro3 in platelets. When we used brain tissue as a positive control, the primers and RT-PCR worked well for Axl and Tyro3 (Figure 2).

ELISA was used to measure protein levels of Gas6, Tyro3, and Axl in platelets. Mouse plasma was used for a positive control and PBS-BSA was used as a negative control. The analytical sensitivity of the assays was $0.7 \mathrm{ng} / \mathrm{mL}$. Gas6 concentration was measured as $26 \mathrm{ng} / \mathrm{mL}$ (22.7-29.1) [median ( $25^{\text {th }}$ percentile- $75^{\text {th }}$ percentile)] in the mouse plasma $(\mathrm{n}=6$ ) and $<0.7 \mathrm{ng} / \mathrm{mL}$ in platelets, which was lower than the 


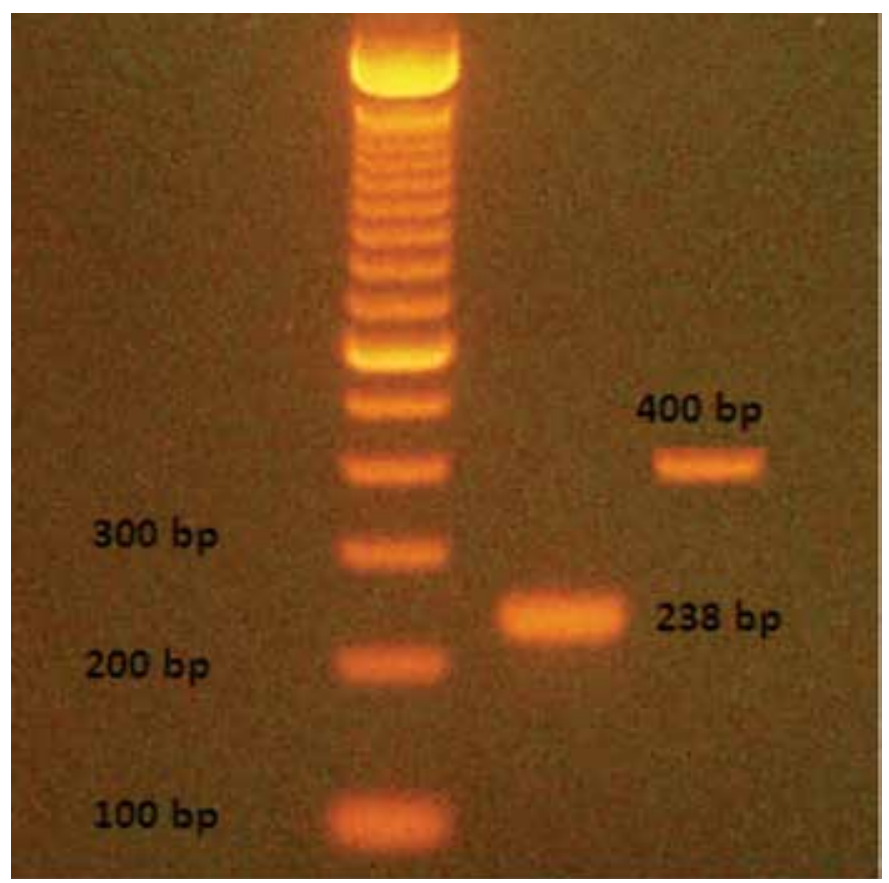

Figure 1. Expression of Gas6 (400 bp) and Mer (238 bp) gene amplifications in mouse platelet by reverse transcriptionpolymerase chain reaction (RT-PCR).

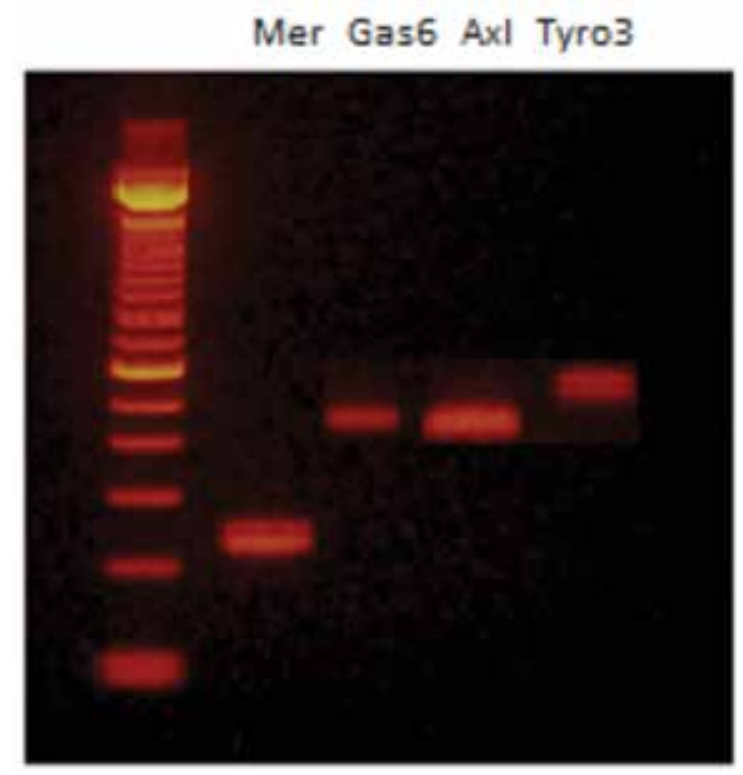

Figure 2. Expression of Gas6 (400 bp) and TAM receptors in mouse brain by reverse transcription-polymerase chain reaction (RT-PCR).

detection limit and very close to the negative control value of PBS-BSA. These results showed us that the Gas6 protein level in the platelets was below the detection limit of ELISA. In the mouse platelets, the protein levels of Axl and Tyro3 were also below the detection limit $(0.7 \mathrm{ng} / \mathrm{mL})$ of the methods.

\section{Discussion}

Gas6 knockout mice studies showed that these mice were resistant to venous and arterial thrombosis and had normal hemostasis parameter values [31]. In parallel with these results, it was shown that TAM receptor knockout mice are resistant to thrombosis and degradation of platelet aggregation. It was suggested that Gas6 increases a tendency to thrombosis by leading to platelet plaque stabilization [32]. The role of Gas6 and its receptors on platelet functions is not clear.

The changes in platelet aggregation or activation have important roles in the pathophysiology of various diseases. There is disagreement as to whether synthesis of Gas6 in mouse platelets plays a role in these alterations. Some research groups have reported contradictory results for the presence of Gas6 and its receptors in mouse platelets. Angelillo-Scherer et al. showed the presence of Gas6 and its 3 receptors in both human and mouse platelets by RT-PCR [32]. In the current study, we found the presence of mRNAs encoding Gas6 and receptor Mer in mouse platelets, but not Axl or Tyro3. Protein Gas6, Axl, and Tyro3 levels were below the detection limits of the ELISA methods.

Chen et al. reported only the presence of receptor Mer in both human and mouse platelets using the western blot and RT-PCR methods [33]. They did not detect the presence of mRNAs for Axl and Tyro3. In Mer knockout mice, they observed impaired platelet functions and a decrease in the responsiveness to low-concentration agonists. Based on these findings, they considered that receptor Mer plays a role in the regulations of platelet functions. Sather et al. observed impaired platelet aggregation in Mer knockout mice [38].

Ishimoto and Nakano reported the presence of Gas6 in rat platelets by ELISA [39]. Moreover, in another study, Balogh et al. used mass spectroscopy and ELISA for measuring Gas6 in human plasma and platelets [40]. They reported that Gas6 levels were $13-23 \mathrm{ng} / \mathrm{mL}$ in human plasma by ELISA. However, in the same study they did not detect Gas6 protein in human platelets.

As a result of RT-PCR reactions, in the current study the presence of mRNAs of Gas6 and Mer was observed in platelets. It is known that platelets do not have DNA, but only RNA. Hence, the presence of mRNA is not obvious evidence of protein synthesis. Although RT-PCR reactions were performed at various temperatures and cycles, no visual band was detected for either Tyro3 or Axl. This agrees with the findings of Chen et al. [33].

One limitation of the current study is that we were unable to measure Mer levels as protein because of the absence of any commercial ELISA kit for mouse Mer. We found that the levels of Gas6 and receptors Axl and Tyro3 in platelets were below the measurable limits of ELISA. 
Further studies are required to clarify the presence of Gas6 and TAM receptors in platelets using real-time PCR and more sensitive immunological methods, as well as studies of their effects on physiological mechanisms. The effects of Gas6 and TAM receptors in clot stabilization are a promising field of research. Further experiments in humans are required to form conclusions as to whether Gas6 may be a reliable pharmacological target in thrombosis, hemostasis, restenosis, and atherosclerosis.

\section{Conflict of Interest Statement}

The authors of this paper have no conflicts of interest, including specific financial interests, relationships, and/or affiliations relevant to the subject matter or materials included.

\section{References}

1. Manfioletti G, Brancolini C, Avanzi G, Schneider C. The protein encoded by a growth arrest-specific gene (gas6) is a new member of the vitamin K-dependent proteins related to protein $\mathrm{S}$, a negative coregulator in the blood coagulation cascade. Mol Cell Biol 1993;13:4976-4985.

2. Saccone S, Marcandalli P, Gostissa M, Schneider C, Della Valle G. Assignment of the human GAS6 gene to chromosome $13 q 34$ by fluorescence in situ hybridization. Genomics 1995;30:129-131.

3. Dahlback B, Villoutreix BO. Regulation of blood coagulation by the protein $C$ anticoagulant pathway: novel insights into structure-function relationships and molecular recognition. Arterioscler Thromb Vasc Biol 2005;25:1311-1320.

4. Stitt TN, Conn G, Gore M, Lai C, Bruno J, Radziejewski C, Mattsson K, Fisher J, Gies DR, Jones PF, Masiakowski P, Ryan TE, Tobkes NJ, Chen DH, DiStefano PS, Long GL, Basilico C, Goldfarb MP, Lemke G, Glass DJ, Yancopoulos GD. The anticoagulation factor protein $S$ and its relative, Gas6, are ligands for the Tyro 3/Axl family of receptor tyrosine kinases. Cell 1995;80:661-667.

5. Nakano T, Higashino K, Kikuchi N, Kishino J, Nomura K, Fujita H, Ohara O, Arita H. Vascular smooth muscle cellderived, Gla-containing growth-potentiating factor for $\mathrm{Ca}^{2+}$ mobilizing growth factors. J Biol Chem 1995;270:5702-5705.

6. Avanzi GC, Gallicchio M, Cavalloni G, Gammaitoni L, Leone F, Rosina A, Boldorini R, Monga G, Pegoraro L, Varnum B, Aglietta M. GAS6, the ligand of Axl and Rse receptors, is expressed in hematopoietic tissue but lacks mitogenic activity. Exp Hematol 1997;25:1219-1226.

7. Neubauer A, Fiebeler A, Graham DK, O'Bryan JP, Schmidt CA, Barckow P, Serke S, Siegert W, Snodgras, HR, Huhn D, Liu ET. Expression of Axl, a transforming receptor tyrosine kinase, in normal and malignant hematopoiesis. Blood 1994;84:19311941.
8. Villoutreix BO, Garcia de Frutos P, Lovenklev M, Linse S, Fernlund P, Dahlback B. SHBG region of the anticoagulant cofactor protein $\mathrm{S}$ : secondary structure prediction, circular dichroism spectroscopy, and analysis of naturally occurring mutations. Proteins 1997;29:478-491.

9. Tjwa M, Bellido-Martin L, Lin Y, Lutgens E, Plaisance S, Bono F, Delesque-Touchard N, Hervé C, Moura R, Billiau AD, Aparicio C, Levi M, Daemen M, Dewerchin M, Lupu F, Arnout J, Herbert JM, Waer M, García de Frutos P, Dahlbäck B, Carmeliet P, Hoylaerts MF, Moons L. Gas6 promotes inflammation by enhancing interactions between endothelial cells, platelets and leukocytes. Blood 2008;111:4096-4105.

10. Hafizi S, Dahlback B. Gas6 and protein S. Vitamin K-dependent ligands for the Axl receptor tyrosine kinase subfamily. FEBS J 2006;273:5231-5244.

11. Tetik S, Uras F, Eksioglu-Demiralp E, Turay Yardimci K. Lowdensity lipoprotein specifically binds glycoprotein IIb/IIIa. A flow cytometric method for ligand-receptor interaction. Clin Appl Thromb Hemost 2008;14:210-219.

12. Ozsavci D, Yardimci T, Demirel GY, Demiralp E, Uras F, Onder E. Flow cytometric assay of platelet glycoprotein receptor numbers in hypercholesterolemia. Platelets 2002;13:223229.

13. Ozsavci D, Yardimci T, Demirel GY, Uras F, Hekim N, Ulutin ON. Apo-Al binding to platelets detected by flow cytometry. Thromb Res 2001;103:117-122.

14. Uras F, Uras AR, Yardimci T, Sardana MK. Determination of the $\mathrm{N}$-terminal amino acid sequence of the purified prothrombin from a patient with liver cirrhosis. Thromb Res 2000;99:277283.

15. Koldas M, Uras F. Avidin-biotin ELISA for measurement of prothrombin in human plasma. Thromb Res 2001;102:221227.

16. Mann KG, Lawson JH. The role of the membrane in the expression of the vitamin K-dependent enzymes. Arch Pathol Lab Med 1992;116:1330-1336.

17. Nakamura YS, Hakeda Y, Takakura N, Kameda T, Hamaguchi I, Miyamoto T, Kakudo S, Nakano T, Kumegawa M, Suda T. Tyro 3 receptor tyrosine kinase and its ligand, Gas6, stimulate the function of osteoclasts. Stem Cells 1998;16:229-238.

18. Hall MO, Obin MS, Heeb MJ, Burgess BL, Abrams TA. Both protein S and Gas6 stimulate outer segment phagocytosis by cultured rat retinal pigment epithelial cells. Exp Eye Res 2005;81:581-591.

19. Healy AM, Schwartz JJ, Zhu X, Herrick BH, Varnum B, Farber HW. Gas6 promotes Axl-mediated survival in pulmonary endothelial cells. Am J Physiol Lung Cell Mol Physiol 2001;280:L1273-1281. 
20. Li R, Chen J, Hammonds G, Phillips H, Armanini M, Wood P, Bunge R, Godowski PJ, Sliwkowski MX, Mather JP. Identification of Gas6 as a growth factor for human Schwann cells. J Neurosci 1996;16:2012-2019.

21. Fridell YW, Villa J Jr, Attar EC, Liu ET. GAS6 induces Axlmediated chemotaxis of vascular smooth muscle cells. J Biol Chem 1998;273:7123-7126.

22. Tjwa M, Moons L, Lutgens E. Pleiotropic role of growth arrest-specific gene 6 in atherosclerosis. Curr Opin Lipidol 2009;20:386-392.

23. Nagata K, Ohashi K, Nakano T, Arita H, Zong C, Hanafusa $\mathrm{H}$, Mizuno K. Identification of the product of growth arrestspecific gene 6 as a common ligand for Axl, Sky, and Mer receptor tyrosine kinases. J Biol Chem 1996;271:3002230027.

24. Sun WS, Fujimoto J, Tamaya T. Coexpression of growth arrest-specific gene 6 and receptor tyrosine kinases Axl and Sky in human uterine endometrial cancers. Ann Oncol 2003;14:898-906.

25. O'Bryan JP, Frye RA, Cogswell PC, Neubauer A, Kitch B, Prokop C, Espinosa R, Le Beau MM, Earp HS, Liu ET. Axl, a transforming gene isolated from primary human myeloid leukemia cells, encodes a novel receptor tyrosine kinase. Mol Cell Biol 1991;11:5016-5031.

26. Faust M, Ebensperger C, Schulz AS, Schleithoff L, Hameister $\mathrm{H}$, Bartram CR, Janssen JW. The murine ufo receptor: molecular cloning, chromosomal localization and in situ expression analysis. Oncogene 1992;7:1287-1293.

27. Ohashi K, Mizuno K, Kuma K, Miyata T, Nakamura T. Cloning of the cDNA for a novel receptor tyrosine kinase, Sky, predominantly expressed in brain. Oncogene 1994;9:699705.

28. Crosier PS, Freeman SA, Orlic D, Bodine DM, Crosier KE. The Dtk receptor tyrosine kinase, which binds protein $\mathrm{S}$, is expressed during hematopoiesis. Exp Hematol 1996;24:318323.

29. Jia R, Hanafusa H. The proto-oncogene of v-eyk (v-ryk) is a novel receptor-type protein tyrosine kinase with extracellular Ig/GN-III domains. J Biol Chem 1994;269:1839-1844.

30. Graham DK, Dawson TL, Mullaney DL, Snodgrass HR, Earp HS. Cloning and mRNA expression analysis of a novel human protooncogene, c-mer. Cell Growth Differ 1994;5:647-657.
31. Angelillo-Scherrer A, de Frutos P, Aparicio C, Melis E, Savi P, Lupu F, Arnout J, Dewerchin M, Hoylaerts M, Herbert J, Collen D, Dahlback B, Carmeliet P. Deficiency or inhibition of Gas6 causes platelet dysfunction and protects mice against thrombosis. Nat Med 2001;7:215-221.

32. Angelillo-Scherrer A, Burnier L, Flores N, Savi P, DeMol M, Herbert JM, Lemke G, Goff SP, Matsushima GK, Earp HS, Vesin C, Hoylaerts MF, Plaisance S, Collen D, Conway EM, Wehrle-Haller B, Carmeliet P. Role of Gas6 receptors in platelet signaling during thrombus stabilization and implications for antithrombotic therapy. J Clin Invest 2005; 115:237-246.

33. Chen C, Li Q, Darrow AL, Wang Y, Derian CK, Yang J, de Garavilla L, Andrade-Gordon P, Damiano BP. Mer receptor tyrosine kinase signaling participates in platelet function. Arterioscler Thromb Vasc Biol 2004;24:1118-1123.

34. Gould WR, Baxi SM, Schroeder R, Peng YW, Leadley RJ, Peterson JT, Perrin LA. Gas6 receptors Axl, Sky and Mer enhance platelet activation and regulate thrombotic responses. J Thromb Haemost 2005;3:733-741.

35. Chan MC, Mather JP, McCray G, Lee WM. Identification and regulation of receptor tyrosine kinases Rse and Mer and their ligand Gas6 in testicular somatic cells. J Androl 2000;21:291-302.

36. Xiong W, Chen $\mathrm{Y}$, Wang $\mathrm{H}$, Wang $\mathrm{H}$, Wu H, Lu Q, Han D. Gas6 and the Tyro 3 receptor tyrosine kinase subfamily regulate the phagocytic function of Sertoli cells. Reproduction 2008;135:77-87.

37. Katagiri M, Hakeda Y, Chikazu D, Ogasawara T, Takato T, Kumegawa M, Nakamura K, Kawaguchi H. Mechanism of stimulation of osteoclastic bone resorption through Gas6/ Tyro 3, a receptor tyrosine kinase signaling, in mouse osteoclasts. J Biol Chem 2001;276:7376-7382.

38. Sather S, Kenyon KD, Lefkowitz JB, Liang X, Varnum BC, Henson PM, Graham D. A soluble form of the Mer receptor tyrosine kinase inhibits macrophage clearance of apoptotic cells and platelet aggregation. Blood 2007;109:1026-1033.

39. Ishimoto Y, Nakano T. Release of a product of growth arrestspecific gene 6 from rat platelets. FEBS Lett 2000;466:197199.

40. Balogh I, Hafizi S, Stenhoff J, Hansson K, Dahlback B. Analysis of Gas6 in human platelets and plasma. Arterioscler Thromb Vasc Biol 2005;25:1280-1286. 